\title{
Wymagania spawalnicze dla instalacji rurociągowych w systemach dystrybucji gazów wysokiej czystości w przemyśle półprzewodnikowym
}

\author{
Welding requirements for pipelines of high purity \\ gas distribution systems in semiconductor industry
}

\section{Streszczenie}

Hale fabryczne każdego producenta mikroprocesorów wyposażone są w setki kilometrów instalacji rurociągowych wykonanych ze stali stopowej do dystrybucji różnego rodzaju gazów technicznych stosowanych w produkcji elementów półprzewodnikowych. Technologia ich łączenia musi zachować szczelność i odporność na korozję całej instalacji. Ponadto system dystrybucji musi zagwarantować bardzo wysoką czystość gazów, co oznacza, że wysokiej i ultra-wysokiej czystości gaz musi przejść przez rurociąg bez gromadzenia pyłów, wilgoci lub innych zanieczyszczeń. W przeszłości standardy wykonania rurociągów do transportu gazów w przemyśle półprzewodnikowym określały specyfikacje producentów. Tak zwane praktyczne lub standardowe procedury operacyjne (SOP - standard operating procedure) zostały opracowane przez wykonawców instalacji w celu dotrzymania rygorystycznych norm czystości narzuconych przez przemysł półprzewodnikowy. W latach 1993-94 międzynarodowe stowarzyszenie producentów i dostawców dla branży półprzewodnikowej SEMI wprowadziło dwie nowe normy, które dotyczą orbitalnego spawania metodą TIG instalacji do dystrybucji mediów w przemyśle mikroi nano-elektroniki. Przepisami tymi są: SEMI F78 „Zasady spawania metodą TIG systemów dystrybucji mediów do zastosowań w przemyśle półprzewodnikowym" (Practice for Gas Tungsten Arc (GTA) Welding of Fluid Distribution Systems in Semiconductor Manufacturing Applications) - przedstawiają wytyczne dotyczące spawania podczas produkcji i montażu rurociągów oraz SEMI F81 „Specyfikacja dla badań wizualnych i oceny spoin wykonanych metodą TIG w systemach dystrybucji mediów do zastosowań w przemyśle półprzewodnikowym" (Specification for Visual Inspection and Acceptance of Gas Tungsten Arc (GTA) Welds in Fluid Distribution Systems in Semiconductor Manufacturing Applications) - opisują szczegóły badań wizualnych i kryteria oceny spoin. Artykuł opisuje procedury i wymagania tych dwóch norm.

Słowa kluczowe: spawanie orbitalne, spawanie TIG w przemyśle półprzewodnikowym, SEMI F78, SEMI F81

\begin{abstract}
Workshops of every microchip manufacturer are equipped with hundreds kilometers of stainless steel tubing transporting gases used in production. The welding technology must maintain the integrity, corrosion resistance and leek free of the system. Additionally, high and ultra-high purity gases must be able to pass through the piping systems without accumulating particulates, moisture or other contaminates. In the past standards for semiconductor gas lines based on company specifications. Practices or standard operating procedures (SOPs) were issued by contractors to meet the high purity standards set by the industry. The society Semiconductor Equipment and Materials International (SEMI) in 1993-94 introduced two new standards that apply to orbital GTA welding in semiconductor fluid distribution systems. These standards are SEMI F78 "Practice for Gas Tungsten Arc (GTA) Welding of Fluid Distribution Systems in Semiconductor Manufacturing Applications" - a guideline for fabrication, and SEMI F81 "Specification for Visual Inspection and Acceptance of Gas Tungsten Arc (GTA) Welds in Fluid Distribution Systems in Semiconductor Manufacturing Applications" - weld acceptance criteria. The paper present procedures and requirements of these two standards.
\end{abstract}

Keywords: Orbital Welding, GTA Welding in Semiconductor Industry, SEMI F78, SEMI F81

Dr inż. Krystian Meka - Biuro Inżynierskie KMS 


\section{Wstęp}

Hale fabryczne każdego producenta mikroprocesorów wyposażone są w setki kilometrów instalacji rurociągowych wykonanych ze stali stopowej do dystrybucji różnego rodzaju gazów technicznych stosowanych w produkcji elementów półprzewodnikowych. Niektóre z tych mediów są wysoce toksyczne przy bardzo niskich stężeniach, inne są samozapalne w kontakcie z powietrzem, a niektóre z nich są silnie korozyjne.

W związku z tym nie tylko rury powinny zapewnić odporność korozyjną i bezawaryjną eksploatację, ale również technologia ich łączenia musi zachować szczelność i odporność na korozję całej instalacji. Ponadto system dystrybucji musi zagwarantować bardzo wysoką czystość gazów, co oznacza, że musi on przejść przez rurociąg bez gromadzenia pyłów, wilgoci lub innych zanieczyszczeń. Tak wysokie standardy wykonania wymagają stosowania dokładnie sprecyzowanych przepisów.

Przed 1993 rokiem standardy wykonania rurociągów do transportu gazów w przemyśle półprzewodnikowym określały specyfikacje producentów. Tak zwane praktyczne lub standardowe procedury operacyjne (SOP - standard operating procedure) zostały opracowane przez wykonawców instalacji w celu dotrzymania rygorystycznych norm czystości narzuconych przez przemysł półprzewodnikowy. SOP stały się pisemnymi procedurami zapewniającymi wysoką jakość i powtarzalność procesów spawania. Jednak w tym czasie nie było jasno określonych zasad i wspólnych kryteriów dotyczących spawania, które mogłyby być zastosowane w całej branży. Istniejący przepis SEMI F3-94 (Semiconductor Equipment and Materials International - SEMI) mówił wprawdzie o spawaniu orbitalnym, ale nie przedstawiał żadnych wytycznych.

W latach 1993-1994 międzynarodowe stowarzyszenie producentów i dostawców dla branży półprzewodnikowej SEMI wprowadziło dwie nowe normy, które dotyczą orbitalnego spawania metodą TIG instalacji do dystrybucji mediów w przemyśle mikro- i nano-elektroniki. Przepisami, które zastąpiły SEMI F3-94, są: SEMI F78 „Zasady spawania metodą TIG systemów dystrybucji mediów do zastosowań w przemyśle półprzewodnikowym" (Practice for Gas Tungsten Arc (GTA) Welding of Fluid Distribution Systems in Semiconductor Manufacturing Applications) - przedstawiają wytyczne dotyczące spawania podczas produkcji i montażu rurociągów oraz SEMI F81 „Specyfikacja dla badań wizualnych i oceny spoin wykonanych metodą TIG w systemach dystrybucji mediów do zastosowań w przemyśle półprzewodnikowym" (Specification for Visual Inspection and Acceptance of Gas Tungsten Arc (GTA) Welds in Fluid Distribution Systems in Semiconductor Manufacturing Applications) - opisują szczegóły badań wizualnych i kryteria oceny spoin. Te dwa dokumenty miały być wzajemnie komplementarne, tzn. jeżeli zasady przedstawione w F78 zostały dotrzymane podczas spawania, to wykonane spoiny powinny spełniać kryteria oceny określone w F81. Nowe przepisy SEMI zawierają wytyczne dla spawaczy oraz podają kryteria, według których dokonywana jest ocena spoin. Definiują one także terminologię, aby uniknąć nieporozumień na linii spawacz - kontrola jakości.

\section{Wymagania spawalnicze normy SEMI F78-0611}

Przepis SEMI F78-0611 „Zasady spawania metodą TIG systemów dystrybucji mediów do zastosowań w przemyśle półprzewodnikowym" (Practice for Gas Tungsten Arc (GTA) Welding of Fluid Distribution Systems in Semiconductor
Manufacturing Applications) opisuje procedury spawania stali stopowych i innych odpornych na korozję metali i stopów do zastosowań we wspomnianych instalacjach. Spoiny wykonane według tych procedur będą odpowiedniej jakości, aby zapewnić wymaganą wysoką czystość systemu, szczelność i wytrzymałość połączeń w systemach dystrybucji mediów.

Zakres stosowania tego przepisu jest praktycznie ograniczony do automatycznego lub zmechanizowanego spawania orbitalnego bez materiału dodatkowego rur o średnicy do $152,4 \mathrm{~mm}\left(6^{\prime \prime}\right)$ ze stali austenitycznej lub superaustenitycznej oraz odpornych na korozję metali i stopów niklu i tytanu. Przepis ten nie dotyczy zbiorników ciśnieniowych i magazynowych stosowanych również w tych instalacjach.

Dokumenty związane z tym przepisem to, oprócz specyfikacji materiałowych takich jak SEMI F20 i normy ASTM, również standardy spawalnicze, czyli odpowiednie przepisy ASME i AWS:

- ASME BPE - Bioprocessing Equipement Standard,

- ASME B16.25 - Buttwelding Ends,

- ASME B3.3 - Process Piping,

- ASME Boiler and Pressure Vessel Code - Section IX, Qualification Standard for Welding and Brazing Procedures, WeIders, Brazers, and Welding and Brazing Operators,

- AWS A3.0 - Standard Welding Terms and Definitions Including Terms for Adhesive Bonding, Brazing, Soldering, Thermal Cutting, and Thermal Spraying,

- AWS B2.1 - Specification for Welding Procedures and Performance Qualification.

\section{Wymagania ogólne:}

- Stosowane procesy spawania, oprócz dodatkowych wymagań tego przepisu, powinny również spełniać wymagania odpowiednich przepisów ASME BPVC - Section IX, ASME B16.25, ASME B31.3 i AWS B2.1.

- Wszystkie spoiny powinny być wykonane zgodnie z instrukcją WPS i towarzyszącym jej właściwym uznaniem technologii spawania (PQR) i dokumentowane według ASME BPVC - Section IX lub AWS 2.1.

- Uznania stosowanych technologii spawania i umiejętności spawaczy i operatorów powinny spełniać wymagania ASME BPVC - Section IX Art. II i II lub AWS 2.1.

- Spawanie powinno być prowadzone tylko przez certyfikowanych spawaczy i operatorów. Procedura egzaminacyjna powinna obejmować wykonanie minimum 3 poprawnych złączy po kolei (pod rząd), typowych połączeń dla najmniejszych i największych średnic dla każdego rodzaju stosowanego materiału. Ważność uprawnień wygasa po 6 miesiącach przerwy w spawaniu.

- Przygotowanie rur do spawania lub ewentualne sczepianie powinno się odbywać pod ciśnieniem gazu osłonowego, a zamknięcie przepływu gazu jest możliwe dopiero po zakończeniu procesu spawania.

- Spawacze i operatorzy powinni używać odpowiednich do "czystego pomieszczenia" (clean room) rękawiczek przez cały czas podczas spawania oraz kiedy rury i elementy nie są zamknięte w opakowaniu ochronnym.

\section{Wyposażenie:}

- Urządzenie spawalnicze to urządzenie do spawania metodą TIG, prądem stałym z biegunowością ujemną, z elektronicznie kontrolowanym i dynamicznie sterowanym źródłem prądu pulsacyjnego $5 \mathrm{~Hz}$ lub więcej.

- Uchwyty pomocnicze i głowice spawalnicze muszą być czyste i wolne od jakichkolwiek zanieczyszczeń i przebarwień. Głowice spawalnicze powinny się obracać swobodnie i płynnie dla każdej prędkości. Klamry i mocowania powinny być odpowiednie do rodzaju złącza (średnicy rurek) 
i zapobiegać przemieszczeniom większym niż 0,08 mm $\left(0,003^{\prime \prime}\right)$. Uchwyty powinny zapewniać widoczność złącza w celu sprawdzenia poprawności montażu.

- Elektrody wolframowe powinny być dokładnie naostrzone według specyfikacji dla każdego rodzaju głowicy i typu spoiny. Odległość elektrody od materiału (długość łuku spawalniczego) powinna być ustawiona zgodnie z procedurą w celu zapewnienia dokładnego i powtarzalnego odstępu w zakresie do 0,05 mm (0,002"). Zaleca się stosowanie elektrod wolframowych $z$ dodatkiem $2 \%$ Ce lub $2 \%$ La.

- Sprzęt do dostarczania gazu osłonowego powinien być wykonany ze stali nierdzewnej i w miarę możliwości szczelnie zamknięty. Przewody z tworzywa PFA są dopuszczalne tylko na montażu ze względu na swoją elastyczność, przy czym ich długość powinna być ograniczona do nie więcej niż 10 stóp (3048 mm).

- Przepływ gazu osłonowego wewnątrz rury musi być mierzony i kontrolowany.

- Sprzęt do przygotowania brzegów rur do spawania powinien zapewnić dokładność dopasowania - odstęp między brzegami nie większy niż 0,08 mm. Przygotowanie brzegów nie może się odbywać przy użyciu materiałów ściernych aby żadne opiłki nie zanieczyściły wnętrza rury, nie można używać oleju ani innych smarów.

- Sprzęt do cięcia również nie może powodować zanieczyszczenia wnętrza rury. Niektóre narzędzia do cięcia wymagają doprowadzenia ciśnienia gazu ochronnego do wnętrza rury. Cięte końce powinny zapewniać odpowiednie tolerancje lub należy zastosować sprzęt do przygotowania brzegów.

\section{Materiały:}

- Wszystkie materiały powinny być wykonane zgodnie z normą ASTM i atestowane przez wytwórcę. Atestacja powinna być przeprowadzona zgodnie z ASTM A450 art 25.

- Wszystkie austenityczne rury bezszwowe powinny spełniać wymagania SEMI F20 lub specyfikacje zamawiającego.

- Przepływ gazu ochronnego wewnątrz rury jest wymagany podczas spawania, jak również podczas sczepiania (o ile takie jest wymagane).

- Parametry spawania zależą od wybranego gazu osłonowego. Argon z powodu swojego skutecznego oddziaływania jest najczęściej stosowanym gazem osłonowym i ochronnym. Argon i hel są gazami obojętnymi i oba te gazy chronią jeziorko spawalnicze, jednak mają one różny potencjał jonizacji, przewodność cieplną i aktywność chemiczną.

- Mieszanka argonu i wodoru zapobiega utlenianiu oraz pozwala na ograniczenie wielkości natężenia prądu spawania w przypadku takiej samej grubości elementów. Mieszanka argonowo-wodorowa niekorzystnie oddziałuje na materiały ferrytyczne o zawartości ponad $80 \%$ ferrytu. Użycie mieszanki argonowo-wodorowej skraca żywotność elektrody wolframowej. Mieszanki wodorowe o zawartości ponad $5 \%$ wodoru nie są zalecane ze względów bezpieczeństwa.

- Azot powoduje niestabilność łuku spawalniczego przy zawartości w mieszance osłonowej ponad 3\%. Azot jest jednak akceptowalny do ochrony grani spoiny od wewnątrz dla rur austenitycznych i wielu odpornych na korozją stopów. Azot w temperaturze łuku spawalniczego tworzy azotki w niektórych materiałach ferrytycznych (powyżej 80\% ferrytu).

- Gaz ochronny grani stosowany do wewnątrz rury powinien być bardzo wysokiej czystości, powyżej 99,9997\% lub o mniejszej niż 3 ppm całkowitej zawartości zanieczyszczeń (wilgoć, tlen i inne zanieczyszczenia).
Zasady bezpieczeństwa:

- Wyposażenie spawalnicze powinno być użytkowane zgodnie z instrukcją obsługi i obowiązującymi przepisami bezpieczeństwa.

- Spawanie powinno się odbywać zgodnie z mającymi zastosowanie wymaganiami ANSI Z49.1.

- Mieszanki spawalnicze zawierające więcej niż 5\% wodoru nie są rekomendowane $z$ powodu potencjalnego niebezpieczeństwa.

- Zabronione jest spawanie rur austenitycznych, które już wcześniej były używane do dystrybucji mediów korozyjnych.

- Należy zapoznać się z informacjami o spawaniu stali nierdzewnych i dymach spawalniczych.

\section{Badania i próbki:}

- Przed rozpoczęciem spawania dla każdej średnicy, grubości i rodzaju materiału powinna zostać wykonana próbka kwalifikacyjna, przecięta i oceniona na stanowisku. Ta pierwsza próbka standardowa będzie oceniana jako reprezentant wszystkich połączeń tego samego rodzaju.

- Pierwsza próbka kwalifikacyjna powinna być oceniona na zgodność z przepisem SEMI F81. Próbka powinna zostać przecięta i poddana badaniom wizualnym. Kryteria oceny próbki są takie same jak kryteria oceny spoin całego systemu.

- Jeżeli spoina złącza próbnego zostanie oceniona pozytywnie, wszystkie podstawowe i drugorzędne parametry procesu powinny być udokumentowane w procedurze kwalifikacji.

- W przypadku znacznych odstępstw stwierdzonych na spoinach produkcyjnych, wszystkie spoiny należy odrzucić. Wykonane złącza należy usunąć i wykonać ponownie.

- Próbki produkcyjne należy wykonywać systematycznie. Należy je porównać ze spoinami wykonanymi na instalacji i ocenić wg SEMI F81. W przypadku odstępstw stwierdzonych na spoinach produkcyjnych lub w stosunku do SEMI F81, złącza należy odrzucić. Złącze próbne może być złączem produkcyjnym w przypadku, gdy istnieje możliwość jego wizualnej oceny od wewnątrz za pomocą boroskopu lub innego przyrządu. Produkcyjne złącze próbne należy wykonać w przypadku wystąpienia jednej z następujących przesłanek:

- Start lub początek zmiany.

- Zmiana parametrów spawania.

- Zmiana materiału lub wytopu.

- Zmiana średnicy lub grubości ścianki.

- Zmiana temperatury otoczenia $0 \pm 11^{\circ} \mathrm{C}$.

- Zmiana źródła zasilania, bądź sposobu zasilania łącznie z wydłużeniem lub skróceniem przewodów zasilających.

- Zmiana lub wyjęcie elektrody.

- Wymiana sprzętu jak głowicy lub jej rozbudowa.

- W przypadku zaobserwowania nieprawidłowości procesu przez operatora.

- W przypadku znaczących zmian parametrów gazu ochronnego od wewnątrz i od zewnątrz (zmiana źródła lub parametrów przepływu gazu).

- Wszystkie próbki należy wykonać przy tych samych przepływach gazu ochronnego wewnątrz instalacji i gazu osłonowego doprowadzonego do głowicy.

\section{Procedura postępowania:}

- Pisemne procedury powinny obejmować każdą konfigurację i zawierać wszystkie parametry spawania.

- Sprawdzenie parametrów i ich weryfikacja na zgodność z kwalifikowaną procedurą spawania.

- Jednocześnie można wykonywać tylko jedno złącze. 
- Procedura przygotowania złącza:

- Wszystkie przyrządy do cięcia i obróbki końcówek rurek powinny być ostre. Stosowanie jakichkolwiek środków smarujących jest niedopuszczalne.

- Wszystkie wióry po cięciu i obróbce końcówek należy usunąć.

- Powierzchnie przygotowane do spawania muszą być czyste, wolne od tlenków, przebarwień, smarów, odprysków i innych materiałów zakłócających proces spawania.

- Rurki należy rozpakować, ciąć, obrobić końcówki i wyczyścić zgodnie z wymaganiami „czystego pomieszczenia” nie pozostawiając zanieczyszczeń wewnątrz ciętych końców.

- Końce rurek należy odciąć usuwając ewentualne zagniecenia lub przewężenia. Do cięcia należy używać narzędzi zapewniających osiowość cięcia, nie wolno stosować smarów.

- Przygotowanie złącza musi minimalizować możliwość wprowadzania zanieczyszczeń do systemu, jeśli zachodzi potrzeba należy przedmuchać rurki gazem w celu usunięcia zanieczyszczeń.

- Przygotowane końce powinny spełniać wymagania ASTM A632 (lub ASTM A269 dla średnicy większej od 1,27 mm $\left.\left(0,5^{\prime \prime}\right)\right)$ odnoście owalności i grubości ścianki. - Odstęp między przygotowanymi do spawania elementami nie może przekraczać $0,08 \mathrm{~mm}(0,003$ ") na obwodzie. W pojedynczych miejscach maksymalny odstęp nie może być większy niż 0,15 mm (0,006").

- Po przygotowaniu ostrożnie i delikatnie stępić powierzchnie wewnętrzne, aby ich nie zarysować. W przypadku zarysowania końcówki należy przygotować ponownie lub zezłomować.

- Ukosowanie jest niezalecane. Maksymalne stępienie krawędzi powinno być mniejsze niż 10\% grubości ścianki lub 0,13 mm (0,005").

- Wszystkie komponenty powinny spełniać wymagania czystości przed dospawaniem do systemu.

- Narzędzia używane do obróbki i przygotowania rur ze stali stopowych lub stopów nie mogą być używane do stali węglowych. Narzędzia muszą być czyste, wolne od tłuszczów, olejów, kurzu i innych zanieczyszczeń. Należy unikać kontaktu różnych rodzajów materiałów ze sobą.

- Nie jest dopuszczalne gięcia rurek w obszarze spoiny.

- Należy używać tylko narzędzi i procesów, które nie uszkodzą powierzchni i nie pogorszą własności materiałów użytych w systemie.

- Końce rurek należy zakorkować po odcięciu dopływu gazu osłonowego w celu zabezpieczenia przed zanieczyszczeniem.

- Korki usuwać bezpośrednio przed spawaniem.

- Procedura czyszczenia rurek:

- Zaleca się czyszczenie wszystkich rurek po cięciu, a przynajmniej rurki zanieczyszczone podczas przygotowania powinny być czyszczone zgodnie z procedurą.

- W przypadku rurek zanieczyszczonych lub w przypadku konieczności usuwania opiłków po cięciu mechanicznym należy stosować następującą procedurę:

1. Najpierw płukanie zimną dejonizowaną wodą.

2. Następnie płukanie ciepłą wodą $\left(80^{\circ} \mathrm{C}\right)$.

3. Końcowe płukanie strumieniem wody pod ciśnieniem.

4. Suszenie ciepłym azotem $\left(150^{\circ} \mathrm{C}\right)$ pod ciśnieniem, suszenie musi nastąpić bezpośrednio po płukaniu.

5. Bezpośrednio po suszeniu rurki należy zakorkować i zapakować w folię ochronną.

- Gaz osłonowy:

- Podczas spawania należy używać gazu osłonowego grani, którego przepływ powinien być kontrolowany i nastawiany zgodnie z wytycznymi.

- Złącza produkcyjne muszą być wykonywane przy tych samych ustawieniach przepływu gazu, jakie były stosowane do spawania próbek.

- Podczas spawania gaz osłonowy bez przerwy powinien przepływać przez wszystkie elementy systemu, takie jak rurki, złączki, zawory i inne komponenty.

- Urządzenia do spawania orbitalnego powinny zapewniać stały, niezakłócony dopływ gazu ochronnego do głowicy spawalniczej.

- Podczas spawania dopływ gazu osłonowego (od wewnątrz) i ochronnego (do głowicy) musi być zapewniony aż do schłodzenia spoiny i zdjęcia głowicy.

- Dopływ gazu osłonowego i ochronnego powinien odbywać się przez urządzenie pomiarowe w celu zapewnienia właściwego przepływu.

- Przy spawaniu instalacji, która nie może być później wyczyszczona, należy utrzymywać przepływ gazu osłonowego wewnątrz na poziomie 1-2 l/min lub ciśnienie 206 kPa, aż do zakończenia spawania.

- Dopływ gazu od kolektora zbiorczego powinien odbywać się oddzielnymi liniami zasilania do każdej spawanej instalacji.

- Należy zwrócić szczególną uwagę, aby wszystkie linie zasilania były wypełnione gazem osłonowym przed spawaniem.

- Wszystkie zaślepione odgałęzienia muszą być również całkowicie wypełnione gazem osłonowym przed spawaniem.

- Wszystkie spoiny należy wykonać zapewniając odpowiedni przepływ gazu osłonowego wg instrukcji WPS w trakcie oraz po spawaniu.

- Do zaślepionych końców instalacji gaz osłonowy należy wprowadzić dodatkową cienką rurką, zapewniając odpowiednią ochronę grani spoiny.

- Przepływ gazu osłonowego przed i po spawaniu należy prowadzić tak długo, jak to potrzebne, aby uniknąć nieakceptowalnych przebarwień spoiny.

- Nieznaczne zewnętrzne przebarwienia powstałe w skutek utleniania można usunąć natychmiast po spawaniu szczotką ze stali nierdzewnej. Przepływ gazu osłonowego należy zapewnić również podczas czyszczenia, aby uniknąć wprowadzenia zanieczyszczeń do instalacji.

- Elektroda wolframowa:

- Elektrody powinny być wymieniane tak często, jak to konieczne, aby zapewnić odpowiednią jakość spoiny. Zalecana ilość spoin wykonanych tą samą elektrodą zależy od średnicy rurki i wynosi:

- D poniżej 6,35 mm (1/4") - 25-50 spoin.

- $D=9,5-25,4 \mathrm{~mm}\left(3 / 8-1^{\prime \prime}\right)-20-25$ spoin.

- D=25,4-50 mm (1-2") - 10-20 spoin.

- D powyżej $50 \mathrm{~mm} \mathrm{10-15}$ spoin.

- Elektrody wolframowe należy ciąć, nie łamać.

- Dodatkowe wymagania:

- Należy zachować odpowiedni dystans między zaworem a spoiną, aby nie uszkodzić gniazda lub trzpienia zaworu podczas spawania.

- Zawory powinny być zlokalizowane w takich miejscach, aby zapewnić wystarczającą ilość miejsca do ich obsługi podczas użytkowania.

- Zawór musi być schłodzony po spawaniu, przed jego użyciem (przekręceniem) aby uniknąć uszkodzenia gniazda.

- Spawanie w „Czystym pomieszczeniu” (clean room):

- Spawacze powinni przestrzegać procedur czystego pomieszczenia i używać odpowiednich rękawiczek (np. lateksowych) podczas spawania rurek lub komponentów wyjętych z folii ochronnej. 
- Wszystkie używane podczas montażu i spawania narzędzia powinny być czyste i nie mogą być wynoszone oraz użytkowane poza czystym pomieszczeniem.

- O ile to możliwe, jak najwięcej spoin należy wykonać w czystym pomieszczeniu jako spoiny warsztatowe, a tylko te niezbędne bezpośrednio podczas montażu instalacji.

- Spoiny montażowe:

- Jeśli wymagane jest cięcie na instalacji (wcięcie), gaz osłonowy powinien być doprowadzony z obydwu stron, aby uniemożliwić zanieczyszczenie instalacji. W innym przypadku odcinek w kierunku którego przepływa gaz osłonowy powinien być zezłomowany lub wyczyszczony zgodnie z procedurą czyszczenia.

- Ze względów bezpieczeństwa podczas cięcia należy stosować ciśnienie do $35 \mathrm{kPa}$ (5 psi) oraz należy uważać na duże natężenie wypływającego gazu w miejscu cięcia i możliwość wydmuchu zanieczyszczeń, należy chronić siebie i innych przed skaleczeniem lub wypadkiem.

- Przed spawaniem ustawić jeden kierunek przepływu gazu osłonowego.

- O ile to możliwe, wcięcia do instalacji należy dokonywać w pozycji horyzontalnej.

\section{Kontrola i ocena spoin:}

- Wszystkie spoiny powinny być zbadane wizualnie zgodnie z wymaganiami SEMI F81 w 100\% od zewnątrz oraz, jeśli to możliwe, również od wewnątrz.

- Wszystkie elementy instalacji powinny być sprawdzone na zgodność z rysunkiem (wymiary i konfiguracja) w warunkach czystego pomieszczenia, oznakowane, zapakowane i przekazane do ewentualnych dalszych badań.

- Jeśli zostanie wykryta niezgodność element instalacji może być odrzucony lub naprawiony, o ile jest to możliwe i nie zmieni to założonych w specyfikacji parametrów instalacji.

- Spoiny powinny być porównane z próbką produkcyjną. Jeśli zostanie stwierdzona niezgodność spawalnicza, dwie uprzednio wykonane spoiny należy odciąć i poddać badaniom, takim jak próbka produkcyjna. Jeśli którakolwiek z tych spoin nie spełnia wymagań SEMI F81 wszystkie spoiny wykonane zgodnie z tym WPSem należy odrzucić i pospawać ponownie.

\section{Raportowanie:}

- Wszystkie próbki produkcyjne powinny być opisane datą i godziną wykonania oraz znakiem identyfikacyjnym operatora. Próbki i protokoły oceny powinny być przechowywane przez jeden rok.

- W dzienniku spawania powinny być odnotowane wszystkie spoiny wykonane na instalacji oraz złącza próbne i „as built" rysunki wraz z wszystkimi parametrami spawania.

- Wszystkie spoiny muszą być oznaczone numerem kodu oraz rysunkiem w celu ich późniejszej oceny.

\section{Ocena spoin według SEMI F81-1103}

Przepis SEMI F81-1103 „Specyfikacja dla badań wizualnych i oceny spoin wykonanych metodą TIG w systemach dystrybucji mediów do zastosowań w przemyśle półprzewodnikowym" (Specification for Visual Inspection and Acceptance of Gas Tungsten Arc (GTA) Welds in Fluid Distribution Systems in Semiconductor Manufacturing Applications) określa zasady przeprowadzania badań wizualnych oraz kryteria oceny spoin ze stali stopowych i innych odpornych na korozję metali i stopów do zastosowań we wspomnianych instalacjach wykonanych metodą TIG. Spełnienie określonych w tym standardzie kryteriów zapewnia wysoką jakość spoin, wymaganą wysoką czystość systemu oraz szczelność i wytrzymałość połączeń w systemach dystrybucji mediów w przemyśle półprzewodnikowym.

Zakres stosowania tego przepisu jest praktycznie identyczny, jak opisanego wcześniej przepisu SEMI F78-0611 i ograniczony do automatycznego lub zmechanizowanego spawania orbitalnego bez materiału dodatkowego rur o średnicy do $152,4 \mathrm{~mm}\left(6^{\prime \prime}\right)$ ze stali austenitycznej lub superaustenitycznej oraz odpornych na korozję metali i stopów niklu i tytanu. Przepis ten dotyczy spawania rurek, rur, złączek, zaworów w warunkach warsztatowych oraz na montażu.

\section{Wymagania:}

- Spoiny powinny być wykonane zgodne z procedurami i wymaganiami przepisu SEMI F78 "Zasady spawania metodą TIG systemów dystrybucji mediów do zastosowań w przemyśle półprzewodnikowym". Same spoiny powinny spełniać następujące kryteria niniejszego przepisu:

- Spoiny powinny wykazywać kompletny przetop na całym obwodzie powierzchni wewnętrznej. Wielkość grani i jej szerokość powinny być jednakowe na całym obwodzie spoiny.

- Na spoinach niedopuszczalne są pęknięcia powierzchniowe, porowatość lub wtrącenia widoczne okiem nieuzbrojonym lub pod powiększeniem.

- Kształt spoiny nie może redukować jej grubości poniżej grubości materiału podstawowego w żadnym punkcie spoiny. Podtopienia i zaniżenia osi lica są nieakceptowalne. Wklęśnięcia grani są również niedopuszczalne.

- Wklęśnięcia lica nie powinno przekraczać 10\% nominalnej grubości ścianki dla rurek o średnicy powyżej 25,4 mm (1"). Wklęśnięcie lica nie jest dopuszczalne dla rurek o średnicy poniżej 25,4 mm. Wypukłość lica nie powinna przekraczać 10\% nominalnej grubości ścianki. - Wypukłość grani spoiny od wewnątrz również nie powinna przekraczać 10\% nominalnej grubości ścianki.

- Minimalna szerokość grani powinna być równa nominalnej grubości ścianki. Maksymalna szerokość grani nie może być większa niż 2,5 grubości nominalnej.

- Dla danej spoiny maksymalna szerokość grani nie może przekraczać 1,25 jej minimalnej szerokości.

- Odchyłka prostoliniowości grani i lica spoiny nie może przekraczać 35\% nominalnej grubości ścianki.

- Powierzchnia wewnętrzna grani spoiny musi być wolna od porowatości, wtrąceń i żużli widocznych gołym okiem. Drobne wtrącenia żużlowe na zakończeniu spoiny są dopuszczalne, o ile ich średnica nie jest większa niż 10\% nominalnej grubości ścianki.

- Szerokość lica spoiny powinna byś co najmniej 2 razy większa od nominalnej grubości ścianki.

- Ścieg spoiny powinien mieć budowę delikatnie łuskowatą a łuski (od kolejnych impulsów prądowych ze źródła) powinny na siebie nachodzić minimum w 80\% od zewnątrz i w $70 \%$ od wewnątrz spoiny z wyjątkiem zakończenia.

- Ewentualne spoiny sczepne muszą być w całości przetopione i niewidoczne na zewnętrznej i wewnętrznej powierzchni spoiny na całym obwodzie.

- Powierzchnia zewnętrzna spoiny nie może być utleniona. Ewentualne niewielkie warstwy tlenków należy usunąć niezwłocznie po spawaniu szczotką z drutu nierdzewnego o ile nie jest to zabronione przez zamawiającego.

- Na powierzchni wewnętrznej i zewnętrznej spoiny nie może być odbarwień (w systemach wysokiej (HP) i ultra wysokiej (UHP) czystości). Niewielkie niebie- 
skie odbarwienia są dopuszczalne dla średnic powyżej $50 \mathrm{~mm}(2 ")$.

- Przesadzenia osiowe złącza nie mogą być większe niż 10\% nominalnej grubości ścianki.

- Przesadzenia kątowe złącza nie mogą przekraczać 1/2 stopnia (1/8" na stopę lub $10 \mathrm{~mm}$ na $1 \mathrm{~m}$ długości).

- Na zakończenie spawania prąd powinien maleć określony czas (downslope), aby zapobiec powstaniu krateru na końcu spoiny. Dystans między zakończeniem spoiny wewnątrz i na zewnątrz powinien wynosić co najmniej 3 nominalne grubości ścianki.

\section{Metody i narzędzia badawcze:}

- Narzędzia badawcze, powiększenie i oświetlenie powinno być uzgodnione pomiędzy zamawiającym a wykonaw- cą i powinno być określone w zamówieniu.

- Wszystkie używane podczas badań narzędzia powinny być sprawne, nieuszkodzone i wolne od zanieczyszczeń.

\section{Odbiór końcowy:}

- Zamawiający może wymagać w kontrakcie lub w zamówieniu od wytwórcy lub dostawcy poświadczenia wykonania i badań instalacji według tej specyfikacji łącznie z protokołami badań podczas odbioru instalacji.

- Na życzenie dostawca i zamawiający mogą ustalić odbiór instalacji jako „będącej w stanie spełnić” określone wymagania. W tym przypadku należy zaznaczyć, że dostawca nie jest zobowiązany do przeprowadzenia wymaganych badań. Jednakże, jeśli zamawiający wykona te badania i ich wynik będzie negatywny, elementy należy odrzucić.

\section{Podsumowanie}

Spawanie orbitalne TIG ma fundamentalne znaczenie dla rozwoju technologii wytwarzania półprzewodników. Postęp w technologiach spawania, lepsze urządzenia spawalnicze i rozwój nauki o materiałach doprowadziły do poprawy jakości, czystości i powtarzalności spoin.

Normy SEMI, zwłaszcza SEMI F78 i F81 obrazują ogromną ilość wiedzy użytkowników, wykonawców, producentów i operatorów urządzeń spawalniczych oraz personelu kontroli jakości. Ich wspólne doświadczenie przyczyniło się do rozwoju praktycznych standardów spawalniczych dla wymagającego przemysłu półprzewodnikowego. Normy SEMI F78 i F81 bardzo jasno i szczegółowo, krok po kroku opisują procedury i wymagania, które gwarantują wysoką jakość spoin. Przestrzeganie tych procedur (F78) i spełnienie tych wymagań (F81) zapewniają szczelność i wytrzymałość połączeń spawanych w instalacji oraz pożądaną wysoką czystość w systemach dystrybucji gazów w przemyśle półprzewodnikowym.

\section{Literatura}

[1] SEMI F78-0611 Practice for Gas Tungsten Arc (GTA) Welding of Fluid Distribution Systems in Semiconductor Manufacturing Applications.
[2] SEMI F81-1103 Specification for Visual Inspection and Acceptance of Gas Tungsten Arc (GTA) Welds in Fluid Distribution Systems in Semiconductor Manufacturing Applications. 